Portland State University

PDXScholar

Engineering and Technology Management

Faculty Publications and Presentations

8-2-2015

\title{
Supporting Sustainable Technology Cluster Development: A Performance Measurement Problem
}

Elizabeth Gibson

Portland State University

Follow this and additional works at: https://pdxscholar.library.pdx.edu/etm_fac

Part of the Operations Research, Systems Engineering and Industrial Engineering Commons Let us know how access to this document benefits you.

\section{Citation Details}

Gibson, E. (2015, August). Supporting sustainable technology cluster development: A performance measurement problem. In Management of Engineering and Technology (PICMET), 2015 Portland International Conference on (pp. 922-930). IEEE.

This Article is brought to you for free and open access. It has been accepted for inclusion in Engineering and Technology Management Faculty Publications and Presentations by an authorized administrator of PDXScholar. Please contact us if we can make this document more accessible: pdxscholar@pdx.edu. 


\title{
Supporting Sustainable Technology Cluster Development: A Performance Measurement Problem
}

\author{
Elizabeth Gibson \\ Dept. of Engineering and Technology Management, Portland State University, Portland, OR - USA
}

\begin{abstract}
Managers require metrics to measure organizational performance. However, metrics used by organizations that support technology cluster development are poorly understood in the literature. The most frequently referenced indicator for cluster development is regional economic and jobs data. These macro level indicators are not sufficient to measure the performance inside the cluster, leaving champions and policy makers to struggle with ad-hoc trial and error experimentation. The difficulty in defining and developing a performance measurement system is addressed. This paper lays the groundwork for improved approaches towards measuring the performance of technology cluster initiatives.
\end{abstract}

\section{INTRODUCTION}

Thinking about best practices for technology cluster development has changed from providing incentives for large, individual firms to relocate towards fostering an environment that helps technology to emerge and develop more organically [1], [2]. Technology clusters have long been accepted as mechanisms to achieve superior economic performance in a region [3]. Porter modernized Marshall's early work that studies industrial clusters [2], by developing a framework for competitive advantage (diamond) where he validated business clusters as a means for sustainable economic growth [1]. Porter defines a cluster as "a geographically proximate group of interconnected companies and associated institutions in a particular field, linked by commonalities and complementaries" [[4]pg 254]. Through a wealth of both qualitative [5], [6], [7], [8] and quantitative [9], [10], [11] studies, researchers have validated that nurturing and developing a cluster is a better method for regional economic development than to create one.

Initiatives are developed and led by champions to support and increase the commercialization of new technologies as a region develops into a sustainable technology center. Champions have experimented with many different types of organizational structures as they search for superior competitive advantage. Effective organizations have helped regions develop into nationally recognized technology centers [5], [12], [13]. However, there is a gap in the scientific literature that discusses how to measure the performance of these organizations.

Research Universities and science and industrial parks have been successfully used as organizational structures to transfer technology and support emerging technology cluster development [14], [15]. Typically, they are led by champions from the university sector with a deep industrial network. One early example was the development of the Stanford Industrial Park championed by Frederick Terman [16].
However, government started looking for practical organizational structures [17], [18] that supported local entrepreneurship [13] and knowledge transfer [19] beyond the university sector [20]. Influencial champions inside the cluster have also realized that sustaining the economic performance of the region required leadership outside the university sector [21] and agree that the triple helix of government, university and industry must be working collaboratively to increase knowledge transfer along the value chain [14], [22], [23], [24].

Other researchers criticize the Triple Helix model as inadequate because it does not consider institutions for collaboration and institutions for financing [25]. As the environment shifts towards a knowledge economy, "networks linking public and private, domestic, regional, and global sector research and technological development entities" are a key success factor [[26] pg 421]. In general, modern research finds that effective organizations are structured as a not-fotprofit, socially-networked entity with influential stakeholders from five segments: academia, industry, government, support groups for collaboration, and investor groups [27], [28]. Therefore, one critical role of the support organization is to span the boundaries of actors in these five sectors to foster the transfer of knowledge [21].

Champions from the academic, public and private sectors can contribute to the economic success of their regions by understanding the competitive strengths and challenges of their regions' industrial clusters. While there is extensive research examining cluster economic performance [9], [29], [30], operational performance requires extension of the current research [31], [32]. Research that examines the organizational characteristics, outcome and output expectations from the organization, and develops a way to measure them is a critical next step.

The following paper lays the groundwork for improved approaches to measure the performance of organizations created to support technology transfer. Including this introduction, the paper is organized in 6 sections. Section 2 reviews the academic literature on organizations supporting technology clusters, definitions, concepts and relevance. It summarizes the gaps in the literature and brings it up to date. Section 3 outlines the complexity and problems for developing a performance measurement system for a technology cluster support initiatives. Section 4 presents outputs for different types of structures in the technology cluster ecosystem. Included are the outputs of I/UCRC type structures, 5-pillar type structures and the Oregon signature research centers. Data describing outcomes, outputs, and indicators were obtained from a signature research center 
through expert interviews and examination of internal reports. Section 5 compares outputs used by the different organizational structures involved in research-based ecosystems, summarizes the discussion laying the groundwork for improved performance measurement approaches and concludes the paper.

\section{TECHNOLOGY CENTERS, CHAMPIONS AND SUPPORT ORGANIZATIONS}

While the term "technology center" is still gaining definitional consensus in the academic literature, technology centers have been used as structures for knowledge and technology transfer for decades. Unfortunately, it has been used somewhat as an umbrella term in different domains which may add confusion to the definitional debate. In order to clarify a working definition, the literature on technology centers was grouped by domain into: international, national, and regional use of the term.

Internationally, the term has been used to describe institutions such as Entrepreneur Research Centers [29], national research centers in Thailand such as the National Metal and Materials Technology Center (MTEC) [33], knowledge centers in Europe [34], the VCI Technology Center in Germany [35] or Science and Technology centers in India. Internationally, technology centers can also be organizations specifically developed to support a specific technology cluster such as the Sensor Technology Center in Denmark [36].

At the U.S. national level, researchers often use "technology center" to describe a National Science Foundation (NSF) Industry-University Collaborative Research Center (I/UCRC), Engineering Research Center (ERC) [37] or Science and Technology Center (STC) [37].

Researchers concerned about regional economic and technology cluster development will refer to a technology center as either a geographic region known for technology such as "Silicon Valley's role as the dominant technology center" [[38] p 60], and "Austin as an emerging technology center" [[20] p 9]; or, as a specific institution such as the Ben Franklin Technology Center at Lehigh University [39] or the Massachusetts Institute of Technology Center [40]. At times, the literature has used the term "technology center" as a general synonym for an organizational structure such as an incubator [39], a university based research center [41], a technology cluster and a technopolis [42].

A technology center is a geographic region known for superior expertise in commercialization and development of a particular technology.

A technology cluster can emerge in any region that has economic activity attributed to technology; whether or not the actors are working together to benefit the development of the cluster as a whole [43]. Types of clusters with primarily independent actors are commonly referred to as agglomerations. Many years can pass as the cluster grows organically until a champion emerges to catalyze the creation of a formal support initiative. For example, the Silicon Forest is a recognized technology cluster in Oregon; but, is primarily sustained by Intel and Tektronix who are independent companies in the cluster.

Different organizational structures are used to develop different types of technologies as a cluster develops and matures towards becoming a technology center [44], [28]. While literature shows that $\mathrm{I} / \mathrm{U}$ structures are instrumental in the emerging phase of technology clusters, basic research sometimes suffers at the expense of commercialization activities [37]. This could be one reason why many of today's technology centers that were initially supported by university research centers, science parks or other organizations are currently being supported by a 5-pillar organizational structures. They simply outgrew them. Porter [9] and other researchers [20], [45], [24], [46] support this idea as they argue to extend beyond the Triple Helix pillars to include actors in other sectors such as institutions for collaboration (IFCs) and institutions for finance (IFFs) [46].

Table 1 shows the current organizational structure of some well known technology centers as the leading support organization expanded beyond the I/U relationship. Several organically developed through a network of champion led support organizations [47] for many years [19] before evolving from an informal organization to a social network structure conducive for knowledge transfer [48]. Currently, the support organizations listed below are all not-for-profit.

TABLE 1: TECHNOLOGY CENTER EXAMPLES OF STRUCTURE AND FOCUS AREA

\begin{tabular}{|l|l|l|l|l|}
\hline $\begin{array}{l}\text { Technology } \\
\text { Center }\end{array}$ & $\begin{array}{l}\text { Leading } \\
\text { Organization }\end{array}$ & Date & Type of Structure & Technology center focus areas \\
\hline $\begin{array}{l}\text { Silicon Valley } \\
\text { (SV) }\end{array}$ & $\begin{array}{l}\text { SV Leadership } \\
\text { group (previously } \\
\text { SV manufacturing } \\
\text { group) }\end{array}$ & $\begin{array}{l}2005 \\
\text { SVLG }\end{array}$ & $\begin{array}{l}\text { Non-profit advocacy group that } \\
\text { replaced Joint Venture Silicon } \\
\text { Valley (JVSV) as primary support } \\
\text { organization }\end{array}$ & Technology innovation and entrepreneurship \\
\hline Austin Texas & $\begin{array}{l}\text { Greater Austin } \\
\text { Chamber of } \\
\text { Commerce }\end{array}$ & 1920 's & $\begin{array}{l}\text { Non-Profit chamber: 5 pillar } \\
\text { representation }\end{array}$ & $\begin{array}{l}\text { Tech manufacturing, clean tech, life sciences, } \\
\text { software }\end{array}$ \\
\hline $\begin{array}{l}\text { Research } \\
\text { Triangle }\end{array}$ & $\begin{array}{l}\text { Research Triangle } \\
\text { Regional Partnershp } \\
\text { (RTRP) }\end{array}$ & $\begin{array}{l}1959 \\
\text { AEDO } \\
2011\end{array}$ & $\begin{array}{l}\text { Public private partnership (PPP) } \\
\text { research park (RTRP) then AEDO } \\
\text { Certified }\end{array}$ & $\begin{array}{l}\text { Advanced medical care, cleantech, informatics, } \\
\text { defense technologies, pharmaceuticals, nanoscale } \\
\text { technologies }\end{array}$ \\
\hline San Diego & CONNECT & 1985 & 501c Trade Organization & Advanced defense, life sciences \\
\hline
\end{tabular}


2015 Proceedings of PICMET '15: Management of the Technology Age

TABLE 2: ORGANIZATIONS SUPPORTING TECHNOLOGY CENTER DEVELOPMENT

\begin{tabular}{|l|l|l|l|l|}
\hline $\begin{array}{l}\text { Technology } \\
\text { Center }\end{array}$ & $\begin{array}{l}\text { Initial primary } \\
\text { research University }\end{array}$ & $\begin{array}{l}\text { I/U Partnership } \\
\text { Organization }\end{array}$ & $\begin{array}{l}\text { Triple Helix } \\
\text { Organization }\end{array}$ & $\begin{array}{l}\text { 5 Pillar } \\
\text { Organization }\end{array}$ \\
\hline Silicon Valley, CA & $\begin{array}{l}\text { Stanford University } \\
(1939-1950)\end{array}$ & $\begin{array}{l}\text { Stanford Industrial } \\
\text { (Research) Park } \\
(1951)\end{array}$ & $\begin{array}{l}\text { Joint Venture Silicon } \\
\text { Valley (1992) }\end{array}$ & $\begin{array}{l}\text { Silicon Valley } \\
\text { Leadership Group } \\
(2005)\end{array}$ \\
\hline Austin, TX & $\begin{array}{l}\text { University of Texas, } \\
\text { Austin (1960-1976) }\end{array}$ & $\begin{array}{l}\text { Innovation, } \\
\text { Creativity, and } \\
\text { Capital Institute } \\
\left(I^{2}\right)\end{array}$ & $\begin{array}{l}\text { Greater Chamber of } \\
\text { Commerce, Austin }\end{array}$ & $\begin{array}{l}\text { Austin Technology } \\
\text { Incubator (ATI) }\end{array}$ \\
\hline $\begin{array}{l}\text { Research Triangle } \\
\text { Park, NC }\end{array}$ & North Carolina State & $\begin{array}{l}\text { Research Triangle } \\
\text { Development Council } \\
(1956)\end{array}$ & $\begin{array}{l}\text { Research Triangle } \\
\text { Institute (1958) }\end{array}$ & - -------------------- \\
\hline San Diego, CA & $\begin{array}{l}\text { University of California, } \\
\text { San Diego }\end{array}$ & $\begin{array}{l}\text { CONNECT (1985) } \\
\text { CONNECT } \\
\text { Association (2005) }\end{array}$ & $\begin{array}{l}\text { CONNECT } \\
\text { Foundation (2005) }\end{array}$ \\
\hline
\end{tabular}

Research has found that technology clusters have developed faster and with greater impact through determined regional leadership action [49], [50] and sustainable initiatives [51]. Intentionally constructed organizations such as industrial parks and incubators are generally viewed as effective structures to develop emerging technology clusters; but not for sustainability. They are limited because they originated through policy mechanisms with specifically stated objectives.

Research shows that the organizational structure must grow to include a broad network of champions for the regional technology cluster to develop into a nationally recognized center of excellence [19]. Feld considers that a critical mass of entrepreneurs to provide leadership is often less than twelve and these leaders do not come from the government sector [52]. Other researchers using social network analysis (SNA) research methods "find empirical support for Feld's work" and "that entrepreneurs are leading" the technology clusters [53] p 14. Even the Silicon Valley follows this pattern by expanding beyond a research university, to a research park, to a venture corporation to a non-profit advocacy group with representation from the 5 pillars. Another example is CONNECT Association; reformed as a 501c organization to support sustainable growth of the San Diego life sciences technology center. Table 2 highlights organizational changes as different technology clusters developed into well-known technology centers.

A strong champion (godfather/godmother) is critical to start a network of influencers who eventually become involved in a 5-pillar type organization. Today many consider Fred Terman to be the godfather of Silicon Valley because he was not only supporting Stanford graduate students (Hewlett and Packard) to commercialize technology in their garage in 1939; but, also continued to champion the commercialization of technology by founding the Stanford Industrial Park [54]. Following current theory that sustainable technology clusters must grow beyond the I/U sectors and initial godfather, the
Silicon Valley Leadership Group was formed to support and lead development of the technology center of the Silicon Valley region [55].

The technolopolis of Austin, Texas also follows this pattern. The University of Texas in Austin, Texas, was the nexus to foster emerging technology [20]. A technology cluster began to develop further in the region as Kozmetsky, a strong champion and recognized godfather, stepped forward with the ability to link different segments [54]. Through his formation and leadership of the Creativity, and Capital Institute $\left(I C^{2}\right)$, champions and investors were recruited to form a network of influencers [20]. Today, Austin Technology Incubator supports emerging technologies and the formation of new networks to sustain the technology center. For example, the Austin Wireless Alliance (AWA) was formed as a non-profit organization, with primary stakeholders from business, academic, the community and government sectors to support and develop a wireless technology cluster [27].

Expanding upon a framework, first presented by Gibson and Conceiçao [56], figure 1 shows how champions are the nexus of a 5-pillar socially networked structure. In general, these organizations are structured as not-for-profit, publicprivate entities [46], led by multiple entrepreneurial, godfather-like influencers who support multiple technology cluster support initiatives [52], [53].

\section{PERFORMANCE MEASUREMENT CHALLENGES}

With all this complexity, what indicators should be used to measure and compare performance? And, how is superior performance being evaluated today? Through a search of the scientific literature, multiple studies were found that evaluated the performance of technology centers and actors within the centers. Table 2 summarizes the different methodologies being applied to the research area. 


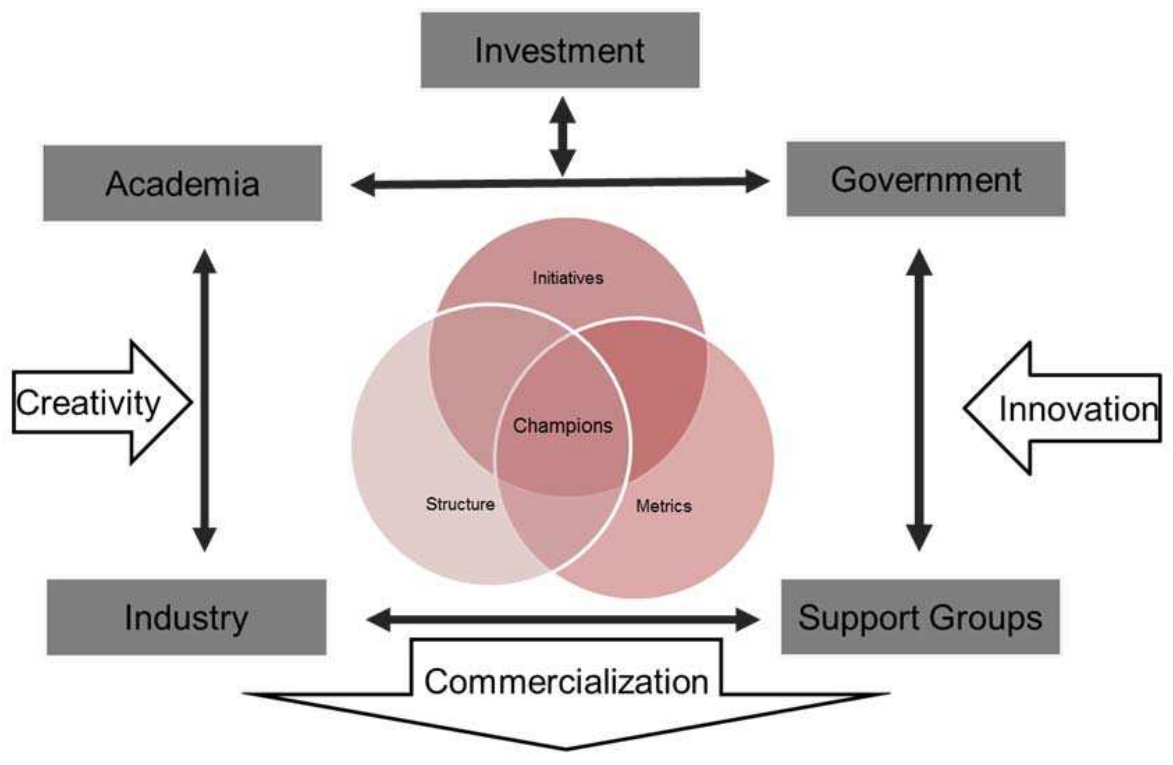

Figure 1: Framework for a 5 pillar organizational structure

TABLE 2: RESEARCH METHODS USED TO MEASURE TECHNOLOGY TRANSFER PERFORMANCE OF DIFFERENT ORGANIZATIONAL STRUCTURES IN TECHNOLOGY CLUSTERS

\begin{tabular}{|l|l|l|l|}
\hline Characteristic & Top-down & Bottom-up & Top-down/Bottom-up \\
\hline Research Question & How Much? & Why and How? & Which One? \\
\hline Approach & Quantitative & Qualitative & Qualitative Quantification \\
\hline Principal Data & Secondary Data & Primary Data & Primary and Secondary \\
\hline Methodology & $\begin{array}{l}\text { Statistical modeling [9], [57], [29], } \\
{[58],[59],[60],[61], \text { SNA [53] }}\end{array}$ & $\begin{array}{l}\text { Case Studies [2], [3], [5], } \\
{[20],[38],[8],[16],[62],} \\
\text { Surveys [63] }\end{array}$ & Multi-Level-Criteria [64], [65], [66] \\
\hline Industrial & Classification System & Descriptive & Multi-Level-Criteria \\
\hline Domain & $\begin{array}{l}\text { Nationwide, Multi-industry cluster, } \\
\text { single industry or single criteria. }\end{array}$ & $\begin{array}{l}\text { Local, single cluster, or } \\
\text { single sector }\end{array}$ & $\begin{array}{l}\text { Nationwide, single industry, single actor } \\
\text { comparisons }\end{array}$ \\
\hline Performance Measures & $\begin{array}{l}\text { Employment, Patents, Wages, } \\
\text { Output, Sales }\end{array}$ & Relationships, Institutions & $\begin{array}{l}\text { \#new products, patents, revenue, } \\
\text { publications, start-ups, network interactions }\end{array}$ \\
\hline
\end{tabular}

Most of the research literature is focused on the need and importance of technology clusters for economic development [67], [46], [68], [69], [70], [71] and the importance of identifying and developing initiatives [16], [72], [38]. Empirical, top-down studies are often used to compare the performance of regional technology clusters for jobs and economic performance at the macro level. Current studies, typically use input/output models with data found in a central database at the cluster mapping project website: www.clustermapping.us. These are lagging indicators and not helpful to understand the inner dynamics and generation of outputs that contribute to the cluster outcome of jobs and economic activity increase.

So, researchers have studied the performance and innovation in industry [64], of US Academic Research centers [58], and technology commercialization centers [29] at the micro level and cluster output at the macro level. Literature recognizes the "missing middle" [73] between the micro (actor) level and the macro (regional cluster) level placing a call-to-arms for more research to examine the efficiency and impact of activities and functions that make up the cluster [13], [19], [9], [72], [67], [16], [3], [74], network dynamics within the cluster [3] and success factors and performance measures of the organizations that support them [59], [43]. Even Porter [9] has called for more research about the impact of cluster composition on regional economic performance and success factors for sustainability.

Agreeing with researchers who recognize this gap [9], [43], [75], Freeman and Soete conclude "research on STI indicators appears today as challenging as ever" [[76] pg 529]. A recent, extensive, research study, provides testimony from multiple experts who agree that "identifying a set of metrics to evaluate the performance of a university-based ecosystem was a considerable challenge" [[63] 4]. So why is this so challenging?

One reason for this gap may be that a technology cluster is a complex ecosystem [77]; not a "trivial machine, with a defined input-output ratio" [78]. Attempting to "understand the nature of an ecosystem" with a "defined input-output ratio" is inadequate and "may well lead to absurd results" [78]. Other researchers agree that it is better to measure outputs rather than inputs if the "objective is to measure the success of knowledge transfer" because the data is intangible and subjective [79]. 
Phan only used output indicators in his research about innovation measurements of high-tech semiconductor companies for similar reasons. Through his use of expert panels, he was able to extract their judgment to evaluate output indicators in a hierarchical decision model he developed [64] to compare the innovation of selected companies in the semi-conductor industry. So, a multi-criteria decision model could be of some help. This approach seems to hold some promise for future research.

Next, champions are tasked with creating "economic and technological values by interacting, competing, and collaborating with other actors in innovation processes, which functions as the source of innovative activities for the region" [[80] pg 463]. Values by nature are subjective and difficult to quantify. Through a literature review, objectives and values were classified by the 5-pillars as shown in figure 2 . The initiative is sustainable only if it delivers the right value to the right stakeholder.

So, the top-down research does not help because the problem is too subjective to be measured by a linear inputoutput model. Some researchers have found promising results using output indicators. However, in a recent survey responding experts generally viewed "commonly used research commercialization metrics as unreliable indicators of long-term capability to support or develop a vibrant innovation ecosystem" [[63] p i]. So, many are questioning if the output metrics being used are even the right ones. Several reasons supporting these findings include:

- Performance of the system is based more on knowledge transfer and flow rather than on efficient use of inputs to provide more outputs such as making people work faster.

- In a linear relationship, actors can control the inputs impacting the results of the performance measurement system.
- Success hinges on the emergence of a godfather/godmother [54] to lead and develop a network of influencers. Sustaining an initiative is difficult, requiring expert leadership ability and an adaptive and iterative approach. It takes art, skill and political influence to build a tight network of diverse champions. The network must be flexible enough to integrate multiple godfathers/godmothers.

- The many different stakeholders value different outcomes and objectives.

- Initiatives need to be supported and take time. Authorities must be willing to make long-term commitments [49]. There are considerable time lags that separate productive outputs from the resource inputs further complicating a linear relationship.

- The I/UCRC model has matured to the point of social technology so the output indicators being used to measure these initiatives are being applied to other organizational structures.

The benefits of a performance measurement system are plentiful. Champions leading the organizational initiatives need performance measures to make decisions. It is also important for the multiple stakeholders to understand the organization's value proposition and performance against that proposition to build trust and remain engaged in the network. Policy makers can also benefit from clear performance measures as they use them to make funding allocation, budget and policy decisions. Finally, taxpayers deserve transparency in decisions made that allocates public funding.

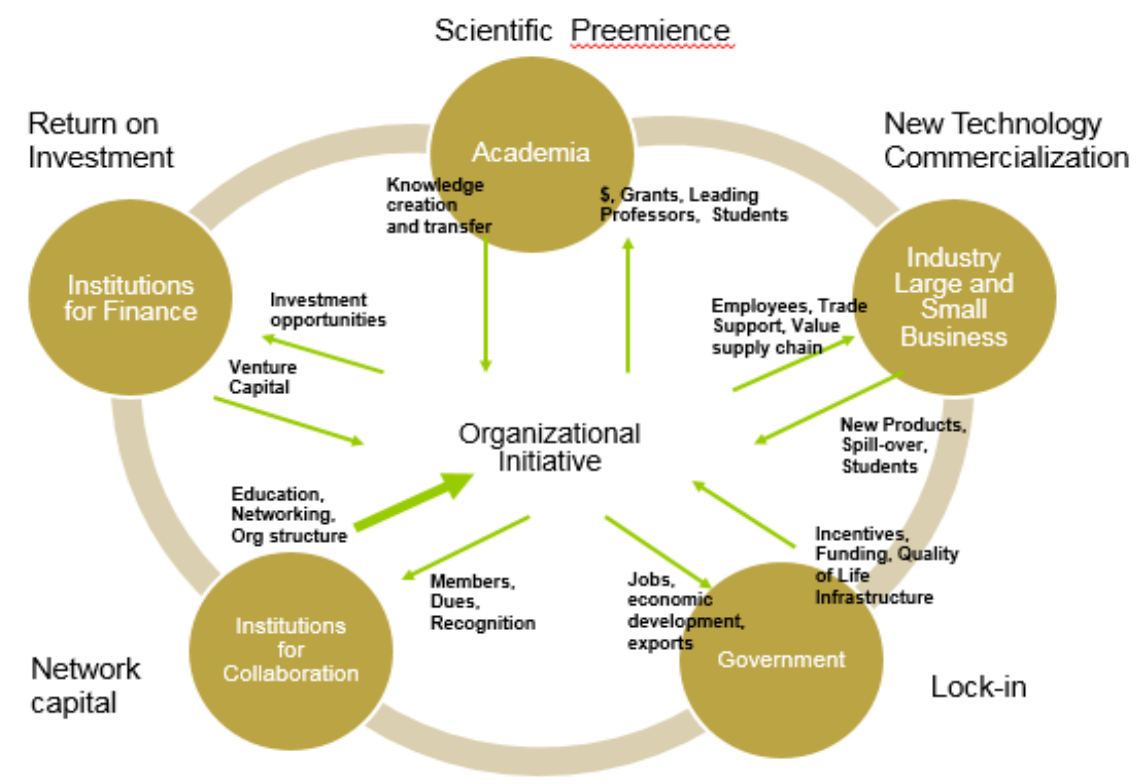

Figure 2: Different economic and technological values by stakeholder pillar 


\section{OBJECTIVES AND OUTPUTS}

According to a White House memorandum [81], funding agencies, academic leadership, and industry must manage their portfolios in an objective, evidence-based manner to address science and technology priorities of our nation and increase the productivity of our research institutions. As discussed, this is easier said than done. Perhaps the most formal, well-funded and structured program is the one established to evaluate the performance of an NSF I/UCRC [82].

There are three types of outputs of I/UCRCs: research, human and social. Research outputs can be classified into publications, presentations, reports, IP and commercialization events. Human outputs include increasingly skilled researchers and managers as well as a growing number of members. Social capital outputs show bonds, bridges and linkages between actors. Social network maps and other graphical representations of relationships and formations are examples of social capital outputs. I/UCRC metrics identified in the literature were synthesized and displayed in table 4.

The results of a content analysis of the technology center performance literature identified four objectives: scientific preeminence[45] [84] [72], new technology commercialization [85], [86], [61], entrepreneurship [2], [29] [61] [65], [58], [87] and intellectual and social capital [86], [84], [29], [49], [88], [75]. There were many additional concepts adding more complexity to the synthesis including ideas of cooperative competition, human capital increases [61] [16], knowledge and innovation conduits [3], social network structure optimization [60], social capital, efficient, mobile and adaptive social networks [72], increasingly complex interactions [26], and knowledge creation from linkages [75]. Many of these outputs coincide with the values identified in figure 2 .

TABLE 4: METRICS USED TO MEASURE I/UCRCS

\begin{tabular}{|c|c|c|c|}
\hline & Outputs & Metrics & Description \\
\hline 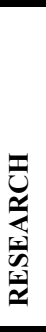 & $\begin{array}{l}\text { Publications } \\
\text { Reports } \\
\text { IP Events }\end{array}$ & $\begin{array}{l}\text { \#pubs/PI } \\
\text { \# pubs/student } \\
\text { \#Cit/pubs/PI } \\
\text { \$R\&D savings } \\
\text { \$R\&D avoidance } \\
\text { \$NSF/\$IAB } \\
\text { \# new processes } \\
\text { \# new products } \\
\text { \#IP Events (other) } \\
\text { NetPreventValue }\end{array}$ & $\begin{array}{l}\text { Quantity of new knowledge } \\
\text { Quantity of new knowledge } \\
\text { Leverage or use of knowledge } \\
\text { Leveraging of funds } \\
\text { New and/or improved processes } \\
\text { New or Improved products }\end{array}$ \\
\hline 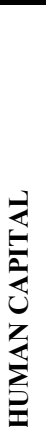 & $\begin{array}{l}\text { Awards/Credentials } \\
\text { Roles } \\
\text { People } \\
\text { Projects }\end{array}$ & $\begin{array}{l}\text { \# faculty(students) } \\
\text { \# degrees earned } \\
\text { \# job offers/student } \\
\text { \# promotions } \\
\text { \#internships/student } \\
\text { \# student/PI } \\
\text { \# IAB members } \\
\text { \# Researchers } \\
\text { \# RFPs, Projects }\end{array}$ & $\begin{array}{l}\text { Awards earned from academic and professional } \\
\text { associations, partner universities } \\
\text { I/UCRC related work } \\
\text { Innovation capacity } \\
\text { Director managerial skill/ability }\end{array}$ \\
\hline 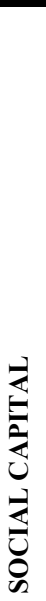 & Bonding & $\begin{array}{l}\text { \#pubs w/IAB mem } \\
\text { \# communication events, } \\
\text { workshops [83] } \\
\text { \#Networking events } \\
\text { Satisfaction survey } \\
\text { \# Spillover } \\
\text { \#new collaborations } \\
\text { Centrality } \\
\text { Betweenness } \\
\\
\text { \# Spin-outs, start-ups } \\
\text { \# Start-up funded (not } \\
\text { bootstrapped) } \\
\text { \$ funded } \\
\text { ROI }\end{array}$ & $\begin{array}{l}\text { Co-authorship and collaboration within IAB } \\
\text { membership information, activity, attendance and } \\
\text { networking opportunities. Networking, events } \\
\text { connections within group. } \\
\text { IAB Satisfaction } \\
\text { Knowledge transfer } \\
\text { Spillover channels } \\
\text { Collaboration SNA maps } \\
\text { Joint research output produced by members of } \\
\text { different organizations } \\
\text { Commercialization events, funded startups. } \\
\text { Knowledge spill-over from the I/UCRC to other } \\
\text { non-member actors. }\end{array}$ \\
\hline
\end{tabular}


The state of Oregon is currently experimenting with different organizational structures to support technology cluster development. After the state of Oregon identified the technology industry as warranting cluster development and support [85], a public-private partnership was formed as the Oregon Innovation Council (Oregon InC). The mission of this organization is to "create innovation into the DNA of how Oregon does business" [89]. As a result, three initiatives were launched over a ten year period and structured as signature research centers (SRCs). The (SRCs) were intentionally created to increase collaboration amongst five of Oregon's public research universities and industry to foster new partnerships for the purpose of increased technology and knowledge transfer. At the same time, others are exploring a 5-pillar model that includes institutions for collaboration and institutions for finance in a formal organizational structure.

Through interviews with experts and evaluation of internal documentation it was found that the signature research centers are not as concerned with basic research outputs as much as they are with applied research and commercialization outputs. The measures are depicted in table 5. Only the social capital outputs identified by the $\mathrm{I} / \mathrm{U}$ type structure in the university based ecosystem actually overlap with technology cluster initiatives as found by this case study.

TABLE 5: OREGON SIGNATURE RESEARCH CENTER METRICS
\begin{tabular}{|l|l|}
\hline Applied Research Outputs & Commercialization Outputs \\
\hline \# companies using lab resources & \# Start-ups in place \\
\# New companies using lab & \# Start-ups created \\
resources & \$ Raised for follow-on funding \\
Leverage of research \$ & Leveraged investment (4:1) \\
& Amount of new out-of-state capital \\
\hline
\end{tabular}

\section{CONCLUSION}

The technology cluster ecosystem is complex and filled with uncertainty with a large range of initiatives to support different stakeholder needs. Different leadership skills and structures are required as a cluster matures into a nationally recognized technology center. While a technology cluster can organically emerge and develop without organized leadership; economic sustainability is risky because it is dependent on independent actors. These type of clusters are agglomerations of companies working independently rather than a technology center with an ever deepening network of entrepreneurs.

Knowledge creation typically starts with basic research at the university. Transfer of technology has been shown to increase through industry/university collaboration. Different structures such as research parks, incubators, accelerators, signature research centers and shared labs have all been effective at increasing knowledge and technology transfer. Ideally, a godfather will initially emerge from academia or industry with the ability to build a network of other influencers into a leadership organization. Then, the process gets less clear.
Through formally organizing, these leaders must then support a variety of long term entrepreneurial development activities. While there is general consensus that a leadership network is necessary, tools and approaches are not sufficient to study the performance of these initiatives. Implementing a new initiative can be risky and expensive. The outputs, indicators and approaches to measure the performance of these initiatives are missing in the literature.

The NSF's I/UCRC has demonstrated a repeatable model for increasing research and technology transfer to industry members. Evaluators have used outputs to evaluate the performance of different centers. However, researchers and NSF program evaluators have identified gaps to measure social network outputs. These types of outputs were common with the types of outputs identified for technology cluster initiative outputs. Because the I/UCRC structure only comprises a subset of the technology cluster ecosystem and the similar outputs are poorly understood, it makes sense there is a "missing middle". Therefore, it is important to understand what types of outcomes, outputs and indicators to measure them are generated by technology center leadership networks.

\section{REFERENCES}

[1] M. E. Porter, "Location, Competition, and Economic Development: Local Clusters in a Global Economy," Econ. Dev. Q., vol. 14, no. 1, pp. 15-34, Feb. 2000.

[2] J. Cortright, "Making sense of clusters: regional competitiveness and economic development," Metropolitan Policy Program, 2006.

[3] E. Giuliani, "Network dynamics in regional clusters: Evidence from Chile," Res. Policy, vol. 42, no. 8, pp. 1406-1419, Sep. 2013.

[4] M. E. Porter, The Competitive Advantage of Nations. New York: The Free Press, 1990, pp. 1-857.

[5] R. W. Smilor, D. V. Gibson, and G. B. Dietrich, "University spin-out companies: Technology start-ups from UT-Austin," J. Bus. Ventur., vol. 5, no. 1, pp. 63-76, Jan. 1990.

[6] J. Wonglimpiyarat, "Commercialization strategies of technology: lessons from Silicon Valley," J. Technol. Transf., vol. 35, no. 2, pp. 225-236, Mar. 2009.

[7] B. Fallick, C. A. Fleischman, and J. B. Rebitzer, "Job-hopping in Silicon Valley: Some evidence concerning the microfoundations of a high-technology cluster," Rev. Econ. Stat., vol. 88, no. 3, pp. 472-481, 1999.

[8] A. Saxenian, "Silicon Valley' s New Immigrant Entrepreneurs," San Fr. Public Policy Inst. Calif., vol. 32, pp. 1-93, 1999.

[9] M. E. Porter, C. Mapping, B. Jones, J. Davis, J. Alcacer, B. Kerr, M. Kahn, J. Dana, W. Gray, M. Macgarvie, A. Mcgahan, A. Bryson, and I. Cockburn, "Clusters, convergence and economic performance," 2012.

[10] P. Aghion, P. a. David, and D. Foray, "Science, technology and innovation for economic growth: Linking policy research and practice in 'STIG Systems,", Res. Policy, vol. 38, no. 4, pp. 681-693, May 2009.

[11] V. Nannen, J. C. J. M. van den Bergh, and A. E. Eiben, "Impact of environmental dynamics on economic evolution: A stylized agentbased policy analysis," Technol. Forecast. Soc. Change, vol. 80, no. 2, pp. 329-350, Feb. 2013.

[12] D. Gibson and D. Mahdjoubi, "Accelerating technology-based growth in developed, developing and emerging regions worldwide.," in Technopolis, 2013, pp. 223-237.

[13] A. Chatterji, E. L. Glaeser, and W. R. Kerr, "Clusters of Entrepreneurship and Innovation," Cam, NBER 19013, 2013. 
[14] H. Etzkowitz and L. Leydesdorff, "The dynamics of innovation: from National Systems and 'Mode 2' to a Triple Helix of universityindustry-government relations," Res. Policy, vol. 29, no. 2, pp. 109123, Feb. 2000.

[15] D. Siegel, D. Waldman, and A. Link, "Assessing the impact of organizational practices on the productivity of university technology transfer offices: An exploratory study," Cambridge, 7256, 1999.

[16] A. Gambardella and A. Saxenian, "Outcomes : Cluster Formation in the New Silicon Valleys," Ind. Corp. Chang., vol. 10, no. 4, pp. 835-860, 2001.

[17] T. U. Daim, G. Rueda, H. Martin, and P. Gerdsri, "Forecasting emerging technologies: Use of bibliometrics and patent analysis," Technol. Forecast. Soc. Change, vol. 73, no. 8, pp. 981-1012, Oct. 2006.

[18] D. K. R. Robinson, L. Huang, Y. Guo, and A. L. Porter, "Forecasting Innovation Pathways (FIP) for new and emerging science and technologies," Technol. Forecast. Soc. Change, vol. 80, no. 2, pp. 267285, Feb. 2013

[19] E. G. Carayannis and M. von Zedtwitz, "Architecting gloCal (globallocal), real-virtual incubator networks (G-RVINs) as catalysts and accelerators of entrepreneurship in transitioning and developing economies: lessons learned and best practices from current development and business incubation," Technovation, vol. 25, no. 2, pp. 95-110, Feb. 2005.

[20] R. W. Smilor, D. V Gibson, and G. Kozmetsky, "Creating the Technopolis : High Technology Development in Austin , Texas," Bus. Ventur., pp. 49-67, 1989.

[21] S. C. Betts and M. D. Santoro, "Somewhere between markets and hierarchies: Controlling industr," Acad. Strateg. Manag. J., vol. 10, no. 1, pp. 19-25, 2011.

[22] A. Comacchio, S. Bonesso, and C. Pizzi, "Boundary spanning between industry and university: the role of Technology Transfer Centres," $J$. Technol. Transf., vol. 37, no. 6, pp. 943-966, Aug. 2011.

[23] J. Alberto and S. Aranha, "Arrangement of actors in the triple helix innovation," in Technopolis, 2013.

[24] F. Phillips, S. Alarakhia, and P. Limprayoon, "The triple helix: International cases and critical summary," in Technopolis, 2013, pp. $67-83$.

[25] B. Kijl, H. Bouwman, T. Haaker, and E. Faber, "Developing a dynamic business model framework for emerging mobile services," in ITS 16th European Regional Conference, 2005.

[26] E. G. Carayannis, D. Popescu, C. Sipp, and M. Stewart, "Technological learning for entrepreneurial development (TL4ED) in the knowledge economy (KE): Case studies and lessons learned," Technovation, vol. 26, no. 4, pp. 419-443, Apr. 2006.

[27] D. V. Gibson and J. S. Butler, "Sustaining the Technopolis: The Case of Austin, Texas," World Technop. Rev., vol. 2, no. 2, pp. 64-80, Aug. 2013.

[28] S. Iammarino and P. McCann, "The structure and evolution of industrial clusters: Transactions, technology and knowledge spillovers," Res. Policy, vol. 35, no. 7, pp. 1018-1036, Sep. 2006.

[29] L. Cassia, A. De Massis, M. Meoli, and T. Minola, "Entrepreneurship research centers around the world: research orientation, knowledge transfer and performance," J. Technol. Transf., pp. 376-392, Feb. 2013.

[30] G. M. Spencer, T. Vinodrai, M. S. Gertler, and D. a. Wolfe, "Do Clusters Make a Difference? Defining and Assessing their Economic Performance," Reg. Stud., vol. 44, no. 6, pp. 697-715, Jul. 2010.

[31] A. Comacchio and S. Bonesso, "Performance Evaluation for Knowledge Transfer Organizations: Best European Practices and a Conceptual Framework," 2010.

[32] B. T. McCann and T. B. Folta, "Performance differentials within geographic clusters," J. Bus. Ventur., vol. 26, no. 1, pp. 104-123, Jan. 2011.

[33] P. Suntharasaj, "Bridging the Missing Link between ' Top-down' and ‘ Bottom-up ': A Strategic Policy Model for International Collaboration in Science and Technology," Portland State University, 2013.

[34] J. Douglass, "Universities, the US High Tech Advantage, and the Process of Globalization," 2008.

[35] N. Malanowski and A. Zweck, "Bridging the gap between foresight and market research: Integrating methods to assess the economic potential of nanotechnology," Technol. Forecast. Soc. Change, vol. 74, no. 9, pp. 1805-1822, Nov. 2007.

[36] P. D. Andersen, B. H. Jørgensen, L. Lading, and B. Rasmussen, "Sensor foresight - technology and market," Technovation, vol. 24, no. 4, pp. 311-320, Apr. 2004.

[37] J. D. Adams and E. P. Chiang, "Industry-University Cooperative Research Centers," 2001.

[38] A. Saxenian, "From Brain Drain to Brain Circulation: Transnational Communities and Regional Upgrading in India and China," Stud. Comp. Int. Dev., vol. 40, no. 2, pp. 35-61, Jun. 2005.

[39] S. Mian, "US university-sponsored technology incubators: an overview of management, policies and performance," Technovation, vol. 14, no. 8, pp. 515-528, Oct. 1994.

[40] J. M. Utterback and W. J. Abernathy, "A dynamic model of process and product innovation," Omega, vol. 3, no. 6, pp. 639-656, Dec. 1975.

[41] G. Brown and O. Thomas, "University-industry links: government as blacksmith," Technovation, vol. 1, pp. 85-95, 1981.

[42] R. Smilor, N. O’Donnell, G. Stein, and R. S. Welborn, "The Research University and the Development of High-Technology Centers in the United States," Econ. Dev. Q., vol. 21, no. 3, pp. 203-222, Aug. 2007.

[43] M. Porter, S. Scott, and M. Delgado, "Defining clusters of related industries," NBER Working Paper series 20375, 2014.

[44] D. Aylward, "Innovation-export linkages within different cluster models: a case study from the Australian wine industry," Prometheus, vol. 22, no. 4, pp. 423-437, Dec. 2004.

[45] M. Theroux Fieldsteel, "Building a Successful Technology Cluster," Environmental Protection Agency, Cleveland, 2013.

[46] R. Haak, G. Vora, S. T. Walsh, and C. G. White, "The Role of Economic Cluster Perspectives in Regional Economic Development," World Technop. Rev., vol. 3, no. 1, pp. 17-29, Mar. 2014.

[47] M. J. Waits, "The Added Value of the Industry Cluster Approach to Economic Analysis, Strategy Development, and Service Delivery," Econ. Dev. Q., vol. 14, no. 1, pp. 35-50, Feb. 2000.

[48] F. Phillips, "Toward an Intellectual and Theoretical Foundation for 'Shared Prosperity,"' Syst. Pract. Action Res., vol. 18, no. 6, pp. 547568, Dec. 2005.

[49] C. Ketels, "Recent research on competitiveness and clusters: what are the implications for regional policy?," Cambridge J. Reg. Econ. Soc., vol. 6, no. 2, pp. 269-284, May 2013.

[50] E. Becker, B. Burger, and T. Hulsmann, "tries, universities, R\&D institutes, and governments," in Technopolis, D.-S. Oh and F. Phillips, Eds. Springer, 2013, pp. 23-42.

[51] F. Phillips, "Toward a sustainable technopolis," in Technopolis, 2013, pp. $169-182$.

[52] B. Feld, Startup communities: Building an entrepreneurial ecosystem in your city. John Wiley \& Sons, 2012.

[53] Y. Motoyama, J. Konczal, J. Bell-masterson, and A. Morelix, "Think Locally , Act Locally : Building a Robust Entrepreneurial Ecosystem," 2014.

[54] F. Phillips and J. Lerner, "The Godfathers : Characteristics and Roles of Central Individuals in the Transformation of Techno-Regions * by," $J$. Cent. Cathedra, vol. 1, no. 2, pp. 12-27, 2008.

[55] A. Saxenian, N. C. Dabby, and R. Development, "Creating and Sustaining Regional Collaboration in Silicon Valley? The Case of Joint Venture : Silicon Valley," 2004.

[56] D. V Gibson and P. Conceiçao, "Incubating and Networking Technology Commercialization Centers among Emerging, Developing , and Mature Technopoleis," 2003, pp. 739-749.

[57] J. L. Barbero, J. C. Casillas, M. Wright, and A. Ramos Garcia, "Do different types of incubators produce different types of innovations?," J. Technol. Transf., vol. 39, no. 2, pp. 151-168, Apr. 2013.

[58] J. Kim, "Performance characteristic of US academic research," Portland State University, 2012.

[59] C. Gebhardt and M. C. Pohlmann, "Managing the organisation 2.0: Entrepreneurial spirit and general management competences as early indicators for cluster success and sustainable regional development," $J$. High Technol. Manag. Res., vol. 24, no. 2, pp. 153-160, 2013.

[60] J. He and M. H. Fallah, "Dynamics of Inventor Networks and the Evolution of Technology Clusters," Int. J. Urban Reg. Res., p. n/a-n/a, May 2013. 
[61] G. Criaco, T. Minola, P. Migliorini, and C. Serarols-Tarrés, “'To have and have not': founders' human capital and university start-up survival," J. Technol. Transf., vol. 39, no. 4, pp. 567-593, Jun. 2013.

[62] D. Breznitz and M. Taylor, "The communal roots of entrepreneurialtechnological growth - social fragmentation and stagnation: reflection on Atlanta's technology cluster," Entrep. Reg. Dev., vol. 26, no. 3-4, pp. 375-396, May 2014.

[63] R. Graham, "Technology Innovation Ecosystem Benchmarking Study: Key findings from Phase 1," no. January, p. 24, 2013.

[64] K. Phan, "Innovation Measurement: A Decision Framework to Determine Innovativeness of a Company," Portland State University, 2013.

[65] T. A. Tran, "Strategic Evaluation of University Knowledge and Technology Transfer Effectiveness," Portland State University, 2013.

[66] L. Cricelli, M. Greco, and M. Grimaldi, "The assessment of the intellectual capital impact on the value creation process: a decision support framework for top management," Int. J. Manag. Decis. Mak., vol. 12 , no. 2, p. 146, 2013.

[67] A. B. Eisingerich, S. J. Bell, and P. Tracey, "How can clusters sustain performance? The role of network strength, network openness, and environmental uncertainty," Res. Policy, vol. 39, no. 2, pp. 239-253, Mar. 2010.

[68] J. Keller, C. Markmann, and H. A. von der Gracht, "Foresight support systems to facilitate regional innovations: A conceptualization case for a German logistics cluster," Technol. Forecast. Soc. Change, Jan. 2014.

[69] R. Hassink and S.-H. Berg, "Regional innovation support systems and technopoles," in Technopolis, Springer, 2013, pp. 43-66.

[70] I. R. Gordon and P. Mccann, "Clusters , Innovation and Regional Development Clusters , Innovation and Regional Development," $J$. Econ. Geogr., vol. 5, no. 5, pp. 523-543, 2005.

[71] P. Hajek, R. Henriques, and V. Hajkova, "Visualising components of regional innovation systems using self-organizing maps-Evidence from European regions," Technol. Forecast. Soc. Change, vol. 84, pp. 197-214, May 2014.

[72] S. Casper, "How do technology clusters emerge and become sustainable?," Res. Policy, vol. 36, no. 4, pp. 438-455, May 2007.

[73] M. Muro and B. Katz, "The new cluster moment: how regional innovation can foster the next economy," 2010.

[74] Y. Zhang and H. Li, "Innovation Search of new ventures in a technology cluster: The role of ties with service intermediaries," Strateg. Manag. J., vol. 109, pp. 88-109, 2010.

[75] J. Porta, "How to measure IC in clusters: empirical evidence," $J$. Intellect. Cap., vol. 7, no. 3, pp. 354-380, 2006.
[76] C. Freeman and L. Soete, "Developing science, technology and innovation indicators: What we can learn from the past," Res. Policy, vol. 38, no. 4, pp. 583-589, May 2009.

[77] R. Adner and R. Kapoor, "Value creation in innovation ecosystems: how the structure of technological interdependence affects firm performance in new technology generations," Strateg. Manag. J., vol. 31, pp. 306-333, 2010.

[78] T. Wallner and M. Menrad, "Extending the innovation ecosystem," Proceedings. IXXII ISPIM Conf. Hamburd, Ger., p. unpaginated, 2004.

[79] P. Gardner, A. Fong, and R. Huang, "Measuring the impact of knowledge transfer from public research organisations: a comparison of metrics used around the world," Int. J. Learn. Intellect. Cap., vol. 7, no. 3, pp. 318-327, 2010.

[80] D. Yim, "Development of an innovation cluster in the region: Experience of Gwanggyo technovalley in Korea," in Technopolis, 2013, pp. 461-479.

[81] White House Office of Management and Budget, "Science and Technology Priorities for the FY 2011 Budget," Memoranda 2009: M09-27, 2011. [Online]. Available: www.whitehouse.gov/omb/memoranda_2009. [Accessed: 16-Feb2015].

[82] D. O. Gray and S. G. Walters, "Managing the industry/university cooperative research center: a guide for directors and other stakeholders," p. xix, 322 p., 1998.

[83] D. O. Gray and D. Rivers, "Measuring the Economic Impacts of the NSF Industry / University Cooperative Research Centers Program: A Feasibility Study," Arlington, Virginia, 2012.

[84] J. Khuntia, J. Karimi, M. Tanniru, and A. Meyers, "The University of Colorado Digital Health Consortium Initiative: A Collaborative Model of Education, Research and Service," J. Commer. Biotechnol., vol. 20, no. 3, pp. 2-6, Jul. 2014.

[85] S. A. Martin, "Understanding the ONAMI experience: Success factors and transferability final report," Portland, 2008.

[86] C. Boja, "Clusters Models, Factors and Characteristics," Int. J. Econ. Pract. Theor., vol. 1, no. 1, pp. 1-43, 2011.

[87] J. Teshima and R. D. Rung, "ONAMI Shared User Facilities and Commercialization Programs," 2010 18th Bienn. Univ. Micro/Nano Symp., pp. 1-4, Jun. 2010.

[88] C. Aragon, M. J. Aranguren, C. Iturrioz, and J. R. Wilson, "A social capital approach for network policy learning: the case of an established cluster initiative," Eur. Urban Reg. Stud., vol. 21, no. 2, pp. 128-145, Mar. 2012.

[89] “Oregon4Biz.” [Online]. Available: www.oregon4biz.com. 